\title{
'The Dualism of Human Nature' Translators' Note
}

\author{
Irène Eulriet and William Watts Miller
}

'The Dualism of Human Nature' was made available some time ago in English, and this undoubtedly helped to stimulate the mass of commentary that has grown around the essay and made it well-known. But it is time to replace the old translation, since it is so inadequate and fault-ridden. For example, it involves a systematic impulse to change a Durkheimian collective noun such as our will into English individualized plurals, such as 'our wills'. Or it often cuts things out. Thus it eliminates Durkheim's key talk of creative effervescence, which merely becomes 'creativity'. An opposite tendency is to add things in. A case in point is Durkheim's final sentence:

Everything indicates, on the contrary, that the place of effort will always go on increasing with civilization. (1914a: 221)

Instead we get the bizarre, but much quoted:

To the contrary, all evidence compels us to expect our effort in the struggle between the two beings within us to increase with the growth of civilization. (t.1960: 339)

It is impossible to go over every last detail. But it is relevant to draw attention to the work of Berman, who identifies as many as thirteen basic traps for translators (1999: 53). The old translation of 'The Dualism' definitely falls into some of these, namely, the traps of expansion, simplification, clarification, qualitative impoverishment, destruction of rhythm, destruction of idiomatic phrases and of locutions. Yet while it can be easy to criticize the defects of any given translation, coming up with definite recipes for translation does not follow automatically from this. Rather, translators have the complex task of trying to achieve fidelity and exactitude through a labyrinth of choice-filled routes, requiring any number of 'on the spot' decisions that evade systematic encapsulation. However, our general policy has been to be keep in mind the 'traps' of translation pointed out by Berman, and to follow a few house rules so as to avoid them. 
For example, it seems important to us to make every effort to preserve a sentence's structure, where it is clear that something is given emphasis through its very location, and form is part of meaning. Or again, this is an issue in the case of register, so that plain French needs translation into plain, preferably anglo-saxon English, rather than the high-flown and Latinate. But it is also an issue even in the apparently trivial matter of punctuation. This cannot always be kept the same, thanks to different basic rules of punctuation. Yet Durkheim has his own distinctive, even idiosyncratic, way of doing things - as in the way he uses colons and semi-colons to glue together a whole succession of points into a single vast sentence. It eliminates his 'Durkheimian French' to split these into small, 'normal English' sentences. But it can also jumble up his meaning, and lose the thread of his argument, to disconnect and atomize the points he unites in one sentence, and ties in with the group of points in another. Indeed, since form is here an integral part of meaning, changing it is a bit like just changing our will into individualistic English 'our wills'.

Finally, the journal is a place where we can present the translation in as clean a version as possible, unencumbered by editorial endnotes, however helpful these can sometimes be. It is necessary to say only two things.

(1) Durkheim's talk of le ton vital has been left as it is. It seems almost unrenderable in English, and odd in French, though linked with physiological talk of a dynamogenic increase in le tonus vital.

(2) The title of his book has been translated as The Elemental Forms of Religious Life.

Both points are explained in the piece on dynamogénique and élémentaire, elsewhere in this issue.

\section{References}

Durkheim, E.

1914a 'Le dualisme de la nature humaine et ses conditions sociales', Scientia, 15: 206-221; reprinted in La science sociale et l'action, ed. J-C. Filloux, Paris: PUF, 1970: 314-332; translated in Essays on Sociology and Philosophy, ed. K. H. Wolff, New York: Harper, 1960: 325-340.

Other

Berman, A. 1999 La traduction et la lettre ou l'auberge du lointain, Paris: Ed. du Seuil 